\title{
Comparison of bacterial isolated from burn wounds in ICU and burn ward patients
}

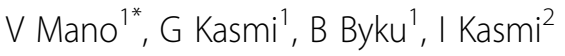 \\ From International Conference on Prevention \& Infection Control (ICPIC 2011) \\ Geneva, Switzerland. 29 June - 2 July 2011
}

\section{Introduction / objectives}

Bacterial infection is of great importance in the course and prognose of burns. Thermal injury creates conditions for the growth of bacteria from the patients own body as well as environmental flora and also depresses host defence mechanisms.

We present the results of isolates from wounds in ICU and burn ward patients.

\section{Methods}

We collected swabs from wounds in 16 ICU patients and 58 of burn ward patients during a two month period Jan.-March 2011. Clinical samples were inoculated on Blood agar and Mac- Conkey agar. The isolates were identified with Gram stain, oxydase test and Enterosystem $18 \mathrm{R}$ for the gram negatives and Staphy slide test for the staphylococci. The antibiogram was performed by the disc-diffusion method, (according to the NCCLS standards).

\section{Results}

$85 \%$ of the patients in the ICU carried Acinetobacter baumanii, 76\% carried both Acinetobacter baumanii and Staphylococcus aureus, both of them very resistant strains. Two patiens carried even a third strain, that of Proteus mirabilis which was partly resistant to antibiotics. While the strains isolated from the burn ward consisted of $42,2 \%$ Pseudomonas aeruginosa, 33,7\% of S. aureus, $8 \%$ Acinetobacter baumanii. The remaining part consisted of Proteus mirabilis, Escherichia coli, Citrobacter freundi, Enterobacter sp.

Acinetobacter was resistant to: Gentamycin, Amikacin, Piperacillin, Ampicillin, Cefotaxim, Cefuroxim, and

"Laboratory of Microbiology, University Hospital Center "Mother Teresa", Tirana, Albania

Full list of author information is available at the end of the article
Ciprofloxacin. All Acinetobacter isolates were susceptible to Piperacillin + Tazobactam and Doripenem.

While S.aureus was susceptible to Eritromicin and Vancomicin and resistant to others.

\section{Conclusion}

We found that Acinetobacter baumanii was the dominant strain in the ICU of burn ward and it has a positive relation to the length of hospitalization in ICU.

\section{Disclosure of interest}

None declared.

\section{Author details}

'Laboratory of Microbiology, University Hospital Center "Mother Teresa", Tirana, Albania. ${ }^{2}$ Pediatric, University Hospital Center "Mother Teresa", Tirana, Albania.

Published: 29 June 2011

doi:10.1186/1753-6561-5-S6-P76

Cite this article as: Mano et al:: Comparison of bacterial isolated from burn wounds in ICU and burn ward patients. BMC Proceedings 20115 (Suppl 6):P76.

Submit your next manuscript to BioMed Central and take full advantage of:

- Convenient online submission

- Thorough peer review

- No space constraints or color figure charges

- Immediate publication on acceptance

- Inclusion in PubMed, CAS, Scopus and Google Scholar

- Research which is freely available for redistribution

Submit your manuscript at www.biomedcentral.com/submit

\section{Biomed Central}

(c) 2011 Mano et al; licensee BioMed Central Ltd. This is an open access article distributed under the terms of the Creative Commons Attribution License (http://creativecommons.org/licenses/by/2.0), which permits unrestricted use, distribution, and reproduction in any medium, provided the original work is properly cited. 